FDA officials say that is exactly the kind of over-regulation they are seeking to avoid. There also are criticisms of the way the NIH group under Walters, which is a subcommittee of RAC is constituted. One FDA official says that somatic cell therapy (the only sort contemplated in the near future) is analogous to many other medical procedures and so should be regulated similarly, by technical experts rather than by lawyers and bioethicists such as are found in Walters' group.

Points to consider describes the documentation needed to support a proposal for gene therapy: structure of the DNA construct, its purity, details of preparation. expression and animal studies; it also outlines the need for informed consent, measures to protect patient confidentiality and accurate information for news media. RAC is already considering one proposal that would allow it to bow out of areas where another agency has assumed responsibility for regulation; under this proposal, however, NIH would decide for themselves which areas to surrender.

Tim Beardsley robably entail treating either LeschNyhan syndrome or adenosine deaminase deficiency, both rare inherited diseases, by infecting patients' bone marrow cells with a retrovirus carrying the gene the patient lacks; the cells would then be replaced in the patient. Points to consider, drafted by a group under LeRoy Walters of Georgetown University, has already been published for comment in the Federal Register and a final version was to have been approved in September. Two weeks ago, however, FDA exercised its new authority as the official "lead agency" for biotechnology regulation and proposed that guidelines on gene therapy or deliberate release of engineered microorganisms should be reviewed by the new Biotechnology Science Board, a body that is to coordinate all federal agencies' interests in biotechnology. Meanwhile, FDA, as lead agency, would take control in areas where jurisdictions overlapped.

The Biotechnology Science Board has as yet no members, however, and it has not even been officially chartered. Faced with abandoning the past two years' work and having to start again, Walters' group has cancelled its September meeting.

The meeting at which FDA staged its coup attempt took place in the absence of $\mathrm{NIH}$ director James Wyngaarden. On learning of the FDA proposals, Wyngaarden met with FDA commissioner Frank Young (long rumoured as a future assistant secretary of health and unofficial "biotechnology czar") and secured an agreement that NIH would go ahead with Points to consider on the understanding that it applied only to NIH-funded research. The document will now once again be published for comment. As the first gene therapy proposals are likely to come from NIH-funded researchers, this measure should at least ensure that someone will read them when they arrive.

There are some points of substance in to be so lax with gene therapy. Researchers will apparently have to seek approval for experiments from both NIH and FDA.

\title{
French science
}

\section{Xenophobia out of fashion}

THIs may not be an auspicious time to speak of an international stance in French scientific and technological relations - after President François Mitterrand has said "non" to star wars research, and after France has pulled out of European advanced fighter-plane project - but this is just what the French council of ministers was doing last week.

In a brief communiqué, the council (the French cabinet) said it wished to "intensify European cooperation", notably in relation to the Eureka project for new European high technology products, and would "reinforce our scientific and technological relations with the United States and Japan".

French research students are also to be encouraged to do their PhDs in collaboration with a foreign university, foreign researchers are to be given a better welcome in France than hitherto, and French scientific diplomatic representation abroad is to be reorganized, the communiqué said.

What this means in practice, however, is difficult to determine. The bid to improve research relations with the United States and Japan was "95 per cent exhortion", according to a French official, as it applied to industry, "over which we have little control", despite French industry's high degree of nationalization. However the intention was clear - to encourage French companies to learn from the Japanese and the Americans how to make a profit out of research: how to apply scientific know-how. For the feeling is that in certain sectors of the French economy, the government may have succeeded in putting researchers in touch with industry - but there is some puzzlement in industry about what to do next.

In relation to universities, last week's communiqué may have more impact "as they take note of what government says". Jean-Pierre Chevènement, as a member of cabinet, has given the communiqué his backing, and must implement its recommendations. Thus it is likely that there will now be pressure on universities to design PhD courses in partial collaboration with foreign universities. How this might be done will be up to the universities, but the "habilitation" system, where universities must apply regularly for specific approvals to run postgraduate courses, would give the minister considerable power to influence the course of events.

Equally, it will be up to Chevènement and minister of research Hubert Curien to implement the recommendation that foreign researchers visiting France should be given better conditions of service. This means better grants for research students visiting France and fewer bureaucratic obstacles for more senior visiting scientists - despite the fact that last year all government-funded research positions became civil service posts.

As for French scientific diplomats, who are thicker on the ground in many countries than those of any other nation, there will be an attempt to "rationalize" their distribution and training, and, according to Paris officials, to cut costs. Many small countries enjoy the presence of a French scientific diplomat even though there is little research: such countries may lose their science counsellor, while larger countries may get more. Robert Walgate. 